\title{
Occurrence of mutations associated with rifampicin and isoniazid resistant in Mycobacterium tuberculosis isolates from patients in Burkina Faso
}

\begin{abstract}
Genetic mutations are responsible for the high rate of resistance observed in the treatment of tuberculosis. This study aimed at determining the occurrence of mutations associated with rifampicin (RIF) and isoniazid (INH) resistance of Mycobacterium tuberculosis complex (MTBC) isolates. MTBC strains isolated by culture from $110 \mathrm{~TB}$ patients diagnosed with resistant to rifampicin (RR-TB) by Xpert MTB/RIF were studied. The isolates were obtained from the National Tuberculosis Reference Laboratory in Ouagadougou. They were identified culturally using Antigenic method (SD Bioline TB Ag MPT64). Polymerase Chain Reaction, PCR (DRplus) was used to detect the occurrence of mutations in the genes associated with resistance kat $G$ and inhA promoter for INH, and $r p o B$ for RIF. Out of 103 isolates with RIF resistant, mutations were detected in $87(84.5 \%)$ of gene $r p o B$ while no mutation was found in $16(15.5 \%)$ of the gene of the isolates even though the wild probes had disappeared. Single mutations were found in the codons D516V (41.7\%) and H526Y (17.5\%) while combined mutations (single and double) were mostly detected in the codons D516 (51.5\%), H526Y (20.4\%), S531L (11.7\%) and H526D (10.7\%) respectively. Single mutations responsible for high-level isoniazid resistance, $k a t G$ were observed in the codon S315T1 while the combined inhA and katG were detected in the codon C8T and S315T, $16(14.5 \%)$ respectively. The highest mutation occurrence was observed with rpoB516, rpoB526 for RIF and katG315 for INH associated with resistance of MTBC isolates. There is a need to improve molecular assay kit diagnosis to curb the geographic specificity of the target genes needed to detect more possible mutations.
\end{abstract}

Keywords: mycobacterium tuberculosis strains, genes, mutations, resistance
Volume 3 Issue 3 - 2019

\author{
Souba Diandé,' Ernest Osamudiamen \\ Ogbomon, ${ }^{2}$ Abdoulaye Gueye, ${ }^{3}$ Adama \\ Diallo,' Léon T Sawadogo,' Bayéma Nébié,' \\ Francis Ouedraogo, ${ }^{5}$ Mourfou Adama, ${ }^{5}$ Issaka \\ Sawadogo, ${ }^{5}$ Lassana Sangaré ${ }^{4}$ \\ 'Programme National de Lutte contre la Tuberculose, Ministère \\ de la Santé, Burkina Faso \\ 2Department of Microbiology, Ahmadu Bello University Zaria, \\ Nigeria \\ ${ }^{3}$ Unité de Formation en Sciences de la Vie et de la Terre, \\ Université Ouaga-I Pr Joseph Ki-Zerbo, Burkina Faso \\ ${ }^{4}$ Unité de Formation en Sciences de la Santé, Université Ouaga-I \\ Pr Joseph Ki-Zerbo, Burkina Faso \\ ${ }^{5}$ Département des laboratoires, Service de Bactériologie- \\ Virologie Ouagadougou, Burkina Faso
}

\begin{abstract}
Correspondence: Souba Diandé, Programme Nationa de Lutte contre la Tuberculose, Ministère de la Santé,

Ouagadougou, Burkina Faso, Tel +22670I I 8360, Fax +2263609

5I,Email diandesouba@hotmail.com
\end{abstract}

Received: June II, 2019 | Published: June 27, 2019

\section{Introduction}

The emergence of multidrug resistant (MDR) strains of MTBC has become one of the most critical issues for tuberculosis (TB) control programmes worldwide. It is a public health concern threatening global TB control programs. Its diagnosis has evolved in recent years following the development of new molecular techniques based on detection of mutations in MTBC genes by Polymerase Chain Reaction (PCR). ${ }^{1-3}$

The Genotype MTBDRplus is a commercially available molecular gene Line Probe Assay developed by Hain Life Science, (Nehren, Germany). It is performed on MTBC isolates or directly from clinical specimens. It able to identify the MTBC and detect the genetic mutations in the $r p o B$ gene related to rifampicin resistance, the $k a t G$, inhA regulatory region and inhA genes related to isoniazid resistance. Its targets points are the 81-bp "hot spot" region of the $r p o B$ gene of RIF, codon 315 of kat $G$ and inhA promoter regions of INH. ${ }^{4-7}$

The genetic basis of multidrug resistant MTB isolates has been widely studied worldwide and commonly believed to be caused by point mutations in important genes like rpoB and kat $G$. Multiple studies carried out at different time periods in the same country/geographical setting have yielded variable incidence of specific $r p o B$ mutation. ${ }^{8,9}$

In Burkina Faso, the fight against MDR-TB/rifampicin-resistant tuberculosis (RR-TB) has become a National concern. For this purpose, the technical platform of the National Reference Laboratory (NRL) for Mycobacteria in Ouagadougou was strengthened with Molecular tests such as Xpert MTB/RIF (Cepheid, Sunnyvale, CA, USA) and
Line Probe Assay (Hain Life Science GmbH, Nehren, Germany). However, other fourteen peripheral Laboratories in the Country have also been equipped with GeneXpert MTB/RIF (Cepheid, Sunnyvale, CA, USA). So, the guidelines of the National Tuberculosis Control Program recommend the use of DRplus and DRsl for all TB-patients confirmed RR-TB by Xpert test (Cepheid, Sunnyvale, CA, USA).

This study was to determine the occurrence of specific $r p o B$, $k a t G$ and inh $A$ gene promoters' mutations in rifampicin and isoniazid resistant M. tuberculosis isolates from TB-patients in Burkina Faso.

\section{Materials and methods}

\section{Study area and laboratory analysis}

We studied rifampicin resistant $M$ tuberculosis strains isolated from $110 \mathrm{~TB}$ patients diagnosed with resistant to rifampicin (RR-TB) by Xpert MTB/RIF (Cepheid, Sunnyvale, CA, USA) at the NRL in Ouagadougou. The patients were undergoing treatment at Centres for Diagnostic Tuberculosis (CDT) between 2014 and 2016 in the 13 Health regions of Burkina Faso. During this period, suspected MDRTB patient's sputa were collected from the various CDTs in the Health regions of the Country and transported to the NRL in Ouagadougou where they were identified culturally using Antigenic method (SD Bioline TB Ag MPT64); thereafter, PCR (DRplus) confirmation. The patients' medical records were review to obtain relevant data on the age, sex, category of patients, HIV status, and region of origin.

\section{Molecular analysis by genotype MTBDR plus $\mathbf{2 . 0}$}

One hundred and ten (110) Mycobacteria tuberculosis isolates were 
selected for the Molecular analysis at the NRL. DNA was extracted using Genolyse ${ }^{\circledR}$ kit (Hain Life Science GmbH, Nehren, Germany). The extracted DNA was processed by the LPA using DRplus (Hain Life Science GmbH, Nehren, Germany) to detect MTBC and RIF and/or INH resistance according to the manufacturer's instructions. ${ }^{7}$ PCR amplification was carried out using biotin-labeled primers. The colorimetric detection of the strips was carried out using enzymes in which DNA products were bound to the strip. Positive internal quality control and negative control were used during the tests. The rроB, $k a t G$, and inhA gene loci each have a control band, the presence of which is mandatory for results interpretation. The presence of $r p o B$ gene locus predicts RIF's resistance while $k a t G$ predicts high level and inhA low-level INH resistance. Absence of wild type and/or presence of mutant band mean resistance to a particular drug. The product insert was further referred for interpretation of banding patterns and trouble shooting.

\section{Limitation of the study}

We have not reported the occurrence of $k a t G$ and $r p o B$ mutations in INH and RMP resistant $M$. tuberculosis isolates from patients of different ethnic background from Burkina Faso. Secondly, among the isolates studied, we do not know which Beijing genotype strains are or not. These two limits did not allow us to understand the higher frequencies of certain mutations compared to the studies that studied them. Thirdly, only DRplus was used to study the occurrence genes mutations.

\section{Statistical analysis}

The results obtained were entered into Statistical Program SPSS version 20.0 and the frequency of patient characteristics and mutations in the $r p o B, k a t G$ and $i n h A$ genes calculated

\section{Results}

\section{Patients' characteristics}

One hundred and ten (110) TB patients with resistant to rifampicin by Xpert test ( 27 females and 83 males) were included. The average age for female patients was 39.9 years (14-70 years), while the male was 36.5 years (16-86 years). Two (2) females and 6 males were tested HIV positive and 26 females and 79 males had a history of TB treatment or were undergoing TB treatment (Table 1). DRplus revealed 76 patients who were resistant to rifampicin, 83 to isoniazid. Among the females, 27 patients were resistant each to rifampicin and isoniazid while 24 were resistant to both isoniazid and rifampicin respectively. The results of Xpert test and DRplus were discordant for 7 patients. This is as presented in Table 1.

\section{Occurrence of mutations in isoniazid and rifampicin resistance associated targets}

In Table 2, out of the 103 isolates with RIF resistant, single mutations were observed in the codons D516V (41.7\%), followed by H526Y (17.5\%) and then S531L (5.8\%). Double mutations in rpoB gene were observed in 6 of the codons D516V+S531L (5.8\%), 3 of $\mathrm{D} 516 \mathrm{~V}+\mathrm{H} 526 \mathrm{Y}(2.9 \%)$ and 1 of $\mathrm{D} 516 \mathrm{~V}+\mathrm{H} 526 \mathrm{D}$ respectively. The occurrence of single and combine mutations in $r p o B$ gene where found to be $51.5 \%$ in the codons D516V, 20.4\% in $\mathrm{H} 526 \mathrm{Y}, 11.7 \%$ in $\mathrm{S} 531 \mathrm{~L}$ and $10.7 \%$ in $\mathrm{H} 526 \mathrm{D}$ respectively while no mutation was found in $16(15.5 \%)$ other cases, even though the wild probes had disappeared.

Table I Patients characteristics

\begin{tabular}{lll}
\hline Characteristics & Sex & \\
\hline & Male (\%) & Female (\%) \\
Number of patients & $83(75.5)$ & $27(24.5)$ \\
Age & $36.5(16-86)$ & $39.9(14-70)$ \\
HIV positive & $6(75.0)$ & $2(25.0)$ \\
HIV negative & $75(75.8)$ & $24(24.2)$ \\
With TB treatment history & $79(80.0)$ & $26(20.0)$ \\
New patients & $4(73.8)$ & $1(26.2)$ \\
RIF- resistance & $76(75.5)$ & $27(24.5)$ \\
INH-resistance & $83(75.5)$ & $27(24.5)$ \\
Both RIF-INH-resistance & $72(75.0)$ & $24(25.0)$ \\
\hline
\end{tabular}

RIF: rifampicin; INH: isoniazid

The mutations responsible for high-level isoniazid resistance in $k a t G$ gene were observed in the codons S315T1 (77.3\%), S315T2 (2.7\%), unknown $(3.6 \%)$ while combined high-level isoniazid resistance mutations in $k a t G$ and inhA gene where observed in the codons $\mathrm{C} 8 \mathrm{~T}+\mathrm{S} 315 \mathrm{~T}(14.5 \%)$ respectively. The mutations responsible for a low level of resistance to isoniazid in inhA were observed in the codons $\mathrm{C} 8 \mathrm{~T}+\mathrm{C} 15 \mathrm{~T}(0.9 \%)$ with unknown mutation $(0.9 \%)$.

\section{Occurrence of codon mutations in rifampicin and isoniazid resistant isolates from different countries/ geographical settings}

The comparison of the occurrence of codon mutations in rifampicin and isoniazid resistant MTBC isolates from different geographic regions is presented in Table $3 \& 4$ respectively. The frequency of 
mutations in the $r p o B$ gene was found in the codons 516, 526 and 531 varied in different geographic regions (Table 3 ). It is the same for the

occurrence of mutations in the $k a t G$ gene and inhA gene promoter (Table 4).

Table 2 Occurrence of mutations in Mycobacterium tuberculosis genes ( $r p o B, k a t G$ and inhA) associated to rifampicin and isoniazid resistance

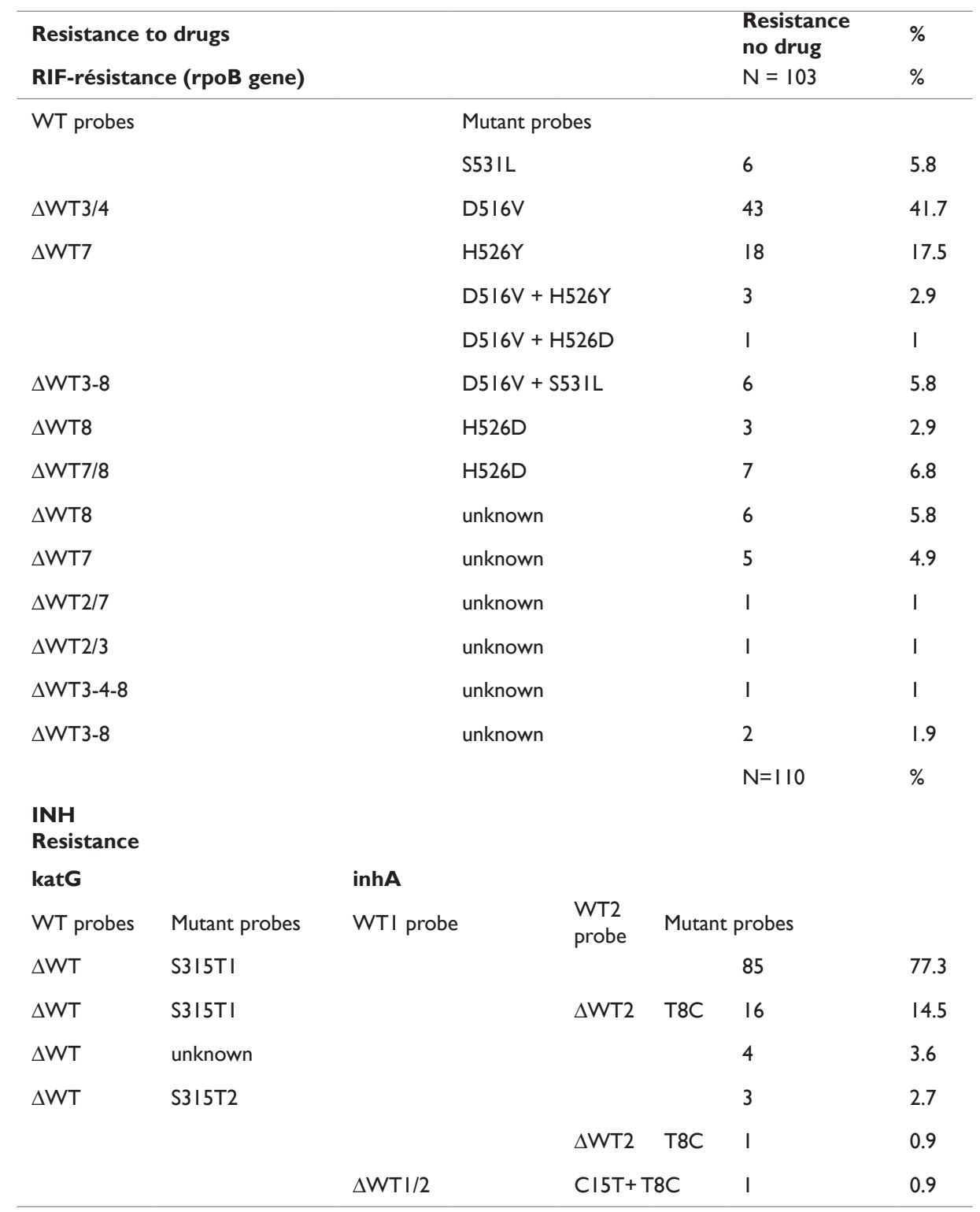

Table 3 Occurrence of codon mutations in rifampicin-resistant M. tuberculosis isolates from different countries/geographical settings

\begin{tabular}{|c|c|c|c|c|c|c|}
\hline Countries & Year & $\mathbf{n}$ & 531 & 516 & 526 & Ref \\
\hline Burkina Faso & 2019 & 103 & $0(0.0)$ & $43(4 I .7)$ & $28(27.2)$ & Our study \\
\hline China & 2018 & 79 & $46(58.2)$ & $8(10.1)$ & $10(12.7)$ & 22 \\
\hline Kyrgyzstan & $2018^{*}$ & 185 & $120(64.8)$ & $15(8.1)$ & $32(17.3)$ & 23 \\
\hline Punjab (India) & 2017 & 137 & $80(58.4)$ & $8(5.8)$ & 12 (8.7) & 24 \\
\hline Ethiopia & $2017^{*}$ & 49 & $40(81.6)$ & I (2.04) & $4(8.16)$ & 25 \\
\hline Ghana & $2017^{*}$ & 13 & $2(15.4)$ & $6(46.2)$ & $3(23.1)$ & II \\
\hline Brasil & 2016 ** & 43 & $27(62.8)$ & - & $3(7.0)$ & 15 \\
\hline South West Ethiopia & $2016 * *$ & 34 & $28(82.4)$ & - & I (2.9) & 16 \\
\hline Ivory Coast & 2016 & 60 & II (I8.3) & $23(38.3)$ & $15(25.0)$ & 12 \\
\hline Nigeria & $2015 * *$ & 10 & $5(50.0)$ & $2(20.0)$ & $3(30.0)$ & 6 \\
\hline
\end{tabular}




\begin{tabular}{lllllll} 
Table Continued & Year & $\mathbf{n}$ & $\mathbf{5 3 1}$ & $\mathbf{5 1 6}$ & $\mathbf{5 2 6}$ & Ref \\
\hline Countries & 2014 & 95 & $16(16.8)$ & $21(22.1)$ & $27(21.1)$ & 13 \\
Ivory Coast & 2013 & 634 & $426(67.2)$ & $33(5.2)$ & $20(3.2)$ & 18 \\
Georgia & $2013^{*}$ & 22 & 68.2 & 4.5 & 4.5 & 26 \\
Taiwan & $2012^{*}$ & 30 & $16(53.3)$ & $3(10.0)$ & $5(16.7)$ & 2 \\
North India & $2012^{*}$ & 15 & $11(73.3)$ & - & $1(6.7)$ & 21 \\
Ethiopia & $2010^{*}$ & 242 & $143(59.1)$ & $12(5.0)$ & $13(5.4)$ & 27 \\
Shanghai (China) & 2009 & 32 & $3(9.4)$ & $14(43.7)$ & $10(31.2)$ & 10 \\
Burkina Faso & 2009 & 107 & $93(86.9)$ & $1(0.9)$ & $2(1.8)$ & 28 \\
Samara (Russia) & 2009 & 2031 & $146(63.2)$ & $6(2.6)$ & $10(13.5)$ & 29 \\
Taipei, Taiwan & & & & &
\end{tabular}

*: only H526Y; **: only H526D

Table 4 Occurrence of codon mutations in isoniazid-resistant Mycobacterium tuberculosis isolates from different countries/geographical settings

\begin{tabular}{|c|c|c|c|c|c|c|c|}
\hline \multirow[t]{2}{*}{ Country } & \multirow[t]{2}{*}{ Year } & \multirow[t]{2}{*}{ Number } & \multicolumn{2}{|l|}{ katG } & \multicolumn{2}{|l|}{$\operatorname{inh} A$} & \multirow[t]{2}{*}{ Reference } \\
\hline & & & S3I5TI & S3I5T2 & C8T & CI5T & \\
\hline Our study & & 110 & $85(77.3)$ & $3(2.7)$ & $\mathrm{I}(0.9)$ & 0 & \\
\hline China & 2018 & 65 & 44 (67.7) & $\mathrm{I}(\mathrm{I} .5)$ & - & $13(20.0)$ & 22 \\
\hline Kyrgyzstan & 2018 & 104 & 91.2 & & - & $8(7.0)$ & 23 \\
\hline Punjab (India) & 2017 & 134 & $110(82.1)$ & I (0.7) & $3(2.2)$ & $17(12.7)$ & 24 \\
\hline Ethiopia & 2017 & 52 & $52(100.0)$ & - & - & - & 25 \\
\hline Ghana & 2017 & 29 & $24(82.8)$ & - & $6(20.7)$ & $5(17.2)$ & 11 \\
\hline South West Ethiopia & 2016 & 41 & $36(87.8)$ & $0(0.0)$ & - & $4(9.8)$ & 16 \\
\hline Brasil & 2016 & 43 & $18(4 \mid .9)$ & & - & II (25.6) & 15 \\
\hline Ivory Coast & 2016 & 59 & $59(100.0)$ & & $16(27.1)$ & - & 12 \\
\hline Nigeria & 2015 & 7 & $3(42.9)$ & - & - & - & 6 \\
\hline Ivory Coast & 2014 & 120 & $76(63.3)$ & - & $24(20.0)$ & I $(0.8)$ & 13 \\
\hline Georgia & 2013 & 634 & $535(84.3)$ & & $8(1.3)$ & $143(22.6)$ & 18 \\
\hline Ethiopia & 2012 & 35 & $33(94.3)$ & - & - & $2(5.7)$ & 21 \\
\hline Burkina Faso & 2009 & 36 & $36(100)$ & & $7(19.4)$ & $3(8.3)$ & 10 \\
\hline Russia & 2009 & 117 & $68(58.1)$ & I (0.9) & - & $3(2.6)$ & 28 \\
\hline Taipei, Taiwan & 2009 & 198 & 96 (48.5) & I (0.5) & $8(3.5)$ & $60(30.3)$ & 29 \\
\hline
\end{tabular}

\section{Discussion}

This study evaluated the occurrence of mutations in the $r p o B$, $k a t G$, and inhA gene promoters responsible for the resistance of $M$. tuberculosis complex to rifampicin and isoniazid in patients detected RR-TB by Xpert MTB/RIF. It revealed mutations in the $r p o B$ gene most commonly at codons D516V, H526Y and S531L. The codon 516 $(51.5 \%)$ had the highest mutations in the rpoB genes. Such a high occurrence agrees with the reports of previous studies in Burkina Faso and other parts of the world; such as ${ }^{10}$ who reported $43.7 \%$ in Burkina Faso ${ }^{11}$ who reported $46.2 \%$ in Ghana. ${ }^{12}$ It is possible that the epidemiology of TB is identical for these Countries. However, the finding was at variance with ${ }^{5,13,14}$ who reported a low occurrence of $2.1 \%, 20.0 \%$ and $21.1 \%$ respectively. Regional variation in the epidemiology of TB could be accounted for these discrepancies.

On the other hand, studies carried out in South West Ethiopia and in Basil have not found a mutation at codon $516 .{ }^{15,16}$ The occurrence of 531 mutations (11.7\%) in this study was comparable to $9.4 \%$ found in the previous study..$^{10}$ Our finding and those of Burkina Faso neighboring countries ${ }^{11,12-14}$ contrast enormously with the results of numerous studies ${ }^{15-29}$ which reported higher rates of mutations at 531 . High rates of 531 mutations were particularly found in Kyrgyzstan, Ethiopia, Brasil, South West Ethiopia, Georgia, Taiwan and Samara in Russia. ${ }^{21,23-28}$ Some authors attributed the variations in the frequency of rpoB-specific mutations to the geographical differences in RMPresistant M. tuberculosis strains circulating in different settings and their clone propagation. ${ }^{28,30}$ So, for Taiwan, codon 531 accounted for $68.2 \%$ of mutations could be due to the spread of a prevalent genetic clone. ${ }^{26}$ The high occurrence of rpoB531 mutation in MDR-TB strains from Samara region in Russian Federation was attributed to the high frequency of Beijing genotype strains, ${ }^{28}$ but that's not a certainty. For instance, the frequency of rpoB531 mutations is much lower in RMPresistant strains in China where the frequency of the Beijing genotype 
strains is high. ${ }^{31}$ The occurrence of mutation at 526 reported in the current study is higher than rate found in Burkina Faso neighbouring Countries, ${ }^{11,12-14}$ lower than the value reported in Nigeria ${ }^{6}$ and similar to findings reported from India and Kyrgyzstan. ${ }^{2,21}$ All this indicates that mutations at codons 531, 526 and 516 are common, with a varied occurrence across the geographical areas.

In this study, occurrence of gene mutation attributed to low level drug resistance mainly caused by the mutations in the promoter region of inhA gene was lower than the mutation frequent C15T observed in Ivory Coast. ${ }^{13}$ Occurrence of katG315 mutations was lower than those obtained in Ghana and in Southwest Ethiopia, ${ }^{11,25}$ similar to an Ivorian study ${ }^{12}$, and higher than a report from Nigerian. ${ }^{6}$ The high occurrence (90-95\%) of katG315 mutations among M. tuberculosis strains in Russia was attributed to the high frequency of Beijing genotype strains. ${ }^{32,33}$ However, the frequency of katG315 mutations is much lower in INH resistant strains in Taiwan, where the frequency of the Beijing genotype strains is high. ${ }^{34,35}$ Some authors reported variations of the occurrence of kat $\mathrm{G} 315$ mutations in isoniazid-resistant isolates among patients of different ethnic groups at the same geographic locations. ${ }^{8}$ It remains to be elucidated whether these differences of variations are due to differences in the genetic background of $M$. tuberculosis isolates or to differences in ethnic origin of the infected TB patients or both.

Our study showed higher level of rifampicin-resistant isolates with no mutation. It corroborated with similar reports from elsewhere. .7,36,37 $^{-17}$ It is possible that less common mutations in $r p o B$ gene cannot be detected by DRplus. ${ }^{21}$ In addition, the possibilities of absence of mutation in RRDR of rpoB gene in MDR-TB isolates may be due to existence of other rare rpoB mutations outside RRDR or different mechanism of rifampicin resistance. ${ }^{38}$ For strains classified as isoniazid-resistant with no mutation, it is known that about $10 \%$ to $25 \%$ of isoniazid-resistance strains are thought to have mutations outside $K a t G$ and inhA loci. Efflux system may play such a role. ${ }^{39,40}$ To cater the geographic specificity of the target genes and be able to detect more possible mutations in different geographical areas, it is necessary to improve molecular assay kit diagnosis. ${ }^{41,42}$

\section{Conclusions}

In Burkina Faso, the general pattern of rpoB, katG and inhA mutations observed is similar to that reported globally in most clinical $M$. tuberculosis isolates. The highest mutation occurrence was observed respectively at 516 and 526 of rpoB, and $k a t G$ (S315T1) genes. However, the DRplus, did not identify certain mutations while the wild probes had disappeared. So, the mutations identified are useful as molecular markers for the detection of multidrug resistant isolates but are not yet sufficient to fully predict a multidrug resistance of M. tuberculosis. Hence the need to improve molecular assay kit diagnosis to cater for the genetic variations associated with the geographic specificity of the target genes and be able to detect most frequent mutations in different geographical areas. Likewise, using phenotypic drug susceptibility testing and sequencing will allow identifying missing mutations not detected by the DRplus.

\section{Acknowledgments}

None

\section{Conflicts of interest}

The authors declare no conflicts of interest.

\section{References}

1. Prasad R, Gupta N, Banka A. Multidrug-resistant tuberculosis rifampicin-resistant tuberculosis: Principles of management. Lung India. 2018;35(1):78-81.

2. Jemil S, Jain MA, Patra SK, et al. Emerging Trend of Mutation Profile of rpoB Gene in MDR. Tuberculosis, North India. Indian J Clin Biochem. 2012;27(4):370-374.

3. Rigouts L, Nolasco O, Rijk P de, et al. Newly developed primers for comprehensive amplification of the rpoB gene and detection of Rifampicin resistance in Mycobacterium tuberculosis. J Clin Microbiol. 2007;45(1):252-254.

4. Hillemann D, Rusch Gerdes S, Richter E. Tuberculosis Strains and Clinical Susceptibility Testing of Mycobacterium Assay for Rifampin and Isoniazid Evaluation of the GenoType MTBDRplus Specimens. J Clin Microbiol. 2007;45(8):2635-2640.

5. Seifert M, Catanzaro D, Catanzaro A, et al. Genetic Mutations Associated with Isoniazid Resistance in Mycobacterium tuberculosis: A Systematic Review. PLoS ONE. 2015;10(3):e0119628.

6. Alfred C, Nyamngee NA, Nwabuisi C, et al. Performance of GenoType MTBDRplus in the Detection of Resistance to Rifampicin and Isoniazid Among Clinical Mycobacteria Isolates in Ilorin, Nigeria. Curr HIV Res. 2015;13(4):308-314.

7. GenoType MTBDR Plus, Ver. 2.0, Instructions for Use, IFU-304A-02, Hain Life Sciences; 2012.

8. Ahmad S, Al Mutairi NM, Mokaddas E. Variations in the occurrence of specific rpoB mutations in rifampicin-resistant Mycobacterium tuberculosis isolates from patients of different ethnic groups in Kuwait. Indian J Med Res. 2012;135(5):756-762.

9. Kigozi E, Kasule GW, Musisi K, et al. Prevalence and patterns of rifampicin and isoniazid resistance conferring mutations in Mycobacterium tuberculosis isolates from Uganda. PLoS ONE. 2018;13(15):e0198091.

10. Miotto P, Saleri N, Dembele M, et al. Molecular detection of rifampin and isoniazid resistance to guide chronic TB patient management in Burkina Faso. Infect Dis. 2009;9:142.

11. Addo KK, Addo SO, Mensah GI, et al. Genotyping and drug susceptibility testing of mycobacterial isolates from population-based tuberculosis prevalence survey in Ghana. BMC Infect Dis. 2017;17(1):743.

12. N'gessan KR, Alagna R, Dutoziet CC, et al. Genotyping of mutations detected with GeneXpert. Int J Mycobac. 2016;5(2):142-147.

13. N'gessan KR, Assi JS, Ouassa T, et al. Assessment of the GenoType MTBDRplus Assay for rifampicin and isoniazid detection on sputum samples in Côte d'Ivoire. Eur J Microbiol Immunol. 2014;4(3):166-173.

14. Assi JS, N'gessan KR, Bamba S, et al. Genetic basis of resistance to rifampin and isoniazid in cases of failure and relapse from first- line drugs in Côte d Ivoire. Int J Curr Microbiol App.Sci. 2014;3(9):775-784.

15. Cafe Oliveira LN, Muniz Sobrinho JdaS, Oliveira Melo SC, et al. Detection of multidrug-resistant Mycobacterium tuberculosis strains isolated in Brazil using a multimarker genetic assay for kat $G$ and $r p o B$ genes. Braz j infect dis. 2016;20(2):166-172.

16. Tadesse M, Aragaw D, Dimah B, et al. Drug resistance-conferring mutations in Mycobacterium tuberculosis from pulmonary tuberculosis patients in South West Ethiopia. Inter J Mycobacteriol. 2016;5(2):185191.

17. Elbir H, Yousif N. Frequency of mutations in the rpoB gene of multidrugresistant Mycobacterium tuberculosis clinical isolates from Sudan. J Infect Dev Ctries. 2014;8(6):796-798. 
18. Shubladze N, Tadumadze N, Bablishvili N. Molecular patterns of multidrug resistance of Mycobacterium tuberculosis in Georgia. Inter $J$ Mycobact. 2013;2(2):73-78.

19. Sharma BK, Bhandari S, Maharjan Bh, et al. Rapid Detection of Rifampicin and Isoniazid Resistant. Mycobacterium tuberculosis Using Genotype MTBDRplus Assay in Nepal. Int Sch Res Notices. 2014;1-6.

20. Ferro BE, Garcia PK, Nieto LM, et al. Predictive value of molecular drug resistance Testing of Mycobacterium tuberculosis isolates in Valle del Cauca, Colombia. J Clin Microbiol. 2013;51(7):2220-2224.

21. Tessema B, Beer J, Emmrich F, et al. Analysis of gene mutations associated with isoniazid, rifampicin and ethambutol resistance among Mycobacterium tuberculosis isolates from Ethiopia. BMC Infect Dis. 2012;12:37.

22. Jian J, Yang X, Yang J, et al. Evaluation of the GenoType MTBDR plus and MTBDRsl for the detection of drug-resistant Mycobacterium tuberculosis on isolates from Beijing, China. Infect Drug Resist. 2018:11:1627-1634

23. Isakova J, Sovkhozova1 N, Vinnikov D, et al. Mutations of rpoB, katG, inhA and ahp genes in rifampicin and isoniazid-resistant Mycobacterium tuberculosis in Kyrgyz Republic. BMC Microbiol. 2018;18(1):22

24. Singhal R, Arora J, Sah GC, et al. Frequency of multidrug resistance and mutations in Mycobacterium tuberculosis isolates from Punjab state of India. J Epidemiol Glob Health. 2017;7(3):175-180.

25. Kebede A, Demisse D, Assefa M, et al. Performance of MTBDRplus assay in detecting multidrug resistant tuberculosis at hospital level. BMC Res Notes. 2017;10(1):661.

26. Lin $\mathrm{YH}$, Tai $\mathrm{CH}$, Li CR, et al. Resistance profiles and rpoB gene mutations of Mycobacterium tuberculosis isolates in Taiwan. J Microbiol Immunol Infect. 2013;46(4):266-270.

27. Luo T, Zhao M, Li X, et al. Selection of mutations to detect multidrugresistant Mycobacterium tuberculosis strains in Shanghai, China. Antimicrob agents chemother. 2010;54(3):1075-1081.

28. Nikolayevskyy V, Balabanova Y, Simak T, et al. Performance of the Genotype ${ }^{\circledR}$ MTBDRplus assay in the diagnosis of tuberculosis and drug resistance in Samara, Russian Federation. BMC Clin Pathol. 2009;9:2.

29. Huang WL, Chen HY, Kuo YM, et al. Performance Assessment of the GenoType MTBDRplus test and DNA sequencing in detection of multidrug-resistant Mycobacterium tuberculosis. J Clin Microbiol. 2009;47(8):2520-2524.

30. Ahmad S, Mokaddas E, Fares E. Characterization of rpoB mutations in rifampin-resistant clinical Mycobacterium tuberculosis isolates from Kuwait and Dubai. Diagn Microbiol Infect Dis. 2002;44(3):245-252.
31. Huang $H$, Jin $Q$, Chen $X$, et al. Characterization of rpoB mutations in rifampin-resistant Mycobacterium tuberculosis isolates in China. Tuberculosis. 2001;24(4):231-235.

32. Marttila HJ, Soini H, Eerola E, et al. A Ser315Thr substitution in $\mathrm{KatG}$ is predominant in genetically heterogeneous multidrugresistant Mycobacterium tuberculosis isolates originating from the St. Petersburg area in Russia. Antimicrob Agents Chemother. 1998;42(9):2443-2445.

33. Mokrousov I, Narvskaya O, Otten T, et al. High prevalence of KatG Ser315Thr substitution among isoniazid-resistant Mycobacterium tuberculosis clinical isolates from northwestern Russia, 19962001. Antimicrob Agents Chemother. 2002;46(5):1417-1424.

34. Jou R, Chen HY, Chiang CY, et al. Genetic diversity of multidrugresistant Mycobacterium tuberculosis isolates and identification of $\mathbf{1 1}$ novel rpoB alleles in Taiwan. J Clin Microbiol. 2005;43(3):1390-1394.

35. Hwang HY, Chang CY, Chang LL, et al. Characterization of rifampin-resistant Mycobacterium tuberculosis in Taiwan. $J$ Med Microbiol. 2003;52(3):239-245.

36. Alonso M, Palacios JJ, Herranz M, et al. Isolation of Mycobacterium tuberculosis strains with a silent Mutation in rpoB Leading to potential misassignment of resistance category. J Clin Microbiol. 2011;49(7):26882690.

37. Tolani MP, Desiree D'souza TB, Mistry NF. Drug resistance mutations and heteroresistance detected using the GenoType MTBDRplus assay and their implication for treatment outcomes in patients from Mumbai, India. BMC Infect Dis. 2012;12:9.

38. Zaw MT, Emran NA, Lin Z. Mutations inside rifampicin-resistance determining region of $\mathrm{rpoB}$ gene associated with rifampicin-resistance in Mycobacterium tuberculosis. J Infect Public Health. 2018;11(5):605610 .

39. Zhang Y, Yew WW. Mechanisms of drug resistance in Mycobacterium tuberculosis. Int J Tuberc Lung Dis. 2015;19(11):1276-1289.

40. Machado D, Couto I, Perdigao J, et al. Contribution of efflux to the emergence of isoniazid and multidrug resistance in Mycobacterium tuberculosis. PLoS One. 2012;7(4):e34538.

41. Viveiros M, Portugal I, Bettencourt R, et al. Isoniazid-induced transient high-level resistance in Mycobacterium tuberculosis. Antimicrob Agents Chemother. 2002;46(9):2804-2810.

42. Takawira FT, Mandishora RSD, Dhlamini Z, et al. Mutations in rpoB and katG genes of multidrug resistant mycobacterium tuberculosis undetectable using genotyping diagnostic methods. Pan Afr Med J. 2017;27:145. 